\title{
The Study on the influence of wave load on the vibration of shaft system
}

\author{
Li Yan ${ }^{1, a}$, Wang Yanwen ${ }^{1, b}$, Cui Longxian ${ }^{1, c}$ \\ 1 Wuhan University of Technology, Wuhan, China \\ aliyanwhut@163.com, ’wangyanwenwhut@163.com, 'gaishan@163.com
}

\begin{abstract}
Keywords: ship hull deformation, wave loads, oil film rigidity, shaft system vibration, natural frequency

Abstract. In order to avoid the vessel deformation affected the safety of the system caused by the wave load. Using the AQWA software to calculate the wave hydrodynamic pressure and using the APDL language to compile the program loading implement wave loads on hull automatically different wave high, researching the changes of separate support stiffness and all the support stiffness for shafting natural frequency. The results show that: from the point of separate bearing stiffness changes view, the stern tube bearing stiffness has effect on the low order natural frequency of the shaft is relatively large, no effect on the high order frequency almost; with the increase of wave height, bearing oil film rigidity improved, the shafting vibration frequency decreases. Therefore, in consideration of hull deformation, this paper lays a foundation for the research on the vibration of the shafting.
\end{abstract}

\section{Introduction}

With the evolution of the background of the times, ships are becoming larger, the direction of the development is high power,the rigidity of the shafting system also continue to increase [1,2], but the rigidity of the hull is relatively smaller, so the influence of ship hull deformation on the alignment and the vibration state of the ship shafting can not be ignored, The position of each bearing is also changed due to the deformation of the hull, which caused the change of the vibration of the ship shafting, that is harmful to the safety of the ship's navigation.Especially the kind of shafting thick short tail shaft model ship, such as large bulk carriers and tankers, their ship shafting rigidity is relatively large, the deformation of the hull very sensitive. Therefore, the study of under wave loads of hull deformation on shafting vibration effect is very important.

The study is mainly based on a container ship, using the ANSYS finite element analysis software to mesh the ship[3,4], Aqwa was then utilized to calculate the wave hydrodynamic pressure, the deformation of ship under different working conditions is obtained.

According to the situation of the hull deformation to calculate the shafting bearing displacement, and the changes in the vibration of shafting. Research results show that, changes in the natural frequency of the shaft on the hull is sensitive.

\section{Calculation Model}

The study is mainly based on a ship 8530teu container ship, the main structure parameters: length between perpendiculars $320.00 \mathrm{~m}$, wide $42.80 \mathrm{~m}$, deep $24.80 \mathrm{~m}$, design draft $14.65 \mathrm{~m}$, displacement 137253t. using ANSYS finite element analysis software to establish 8530teu container ship finite element model, mainly adopts shell163 elements and the beam188 hull plate girder structure simulation. The model includes 95728 unit and 918481 nodes model as shown in Figure 1.

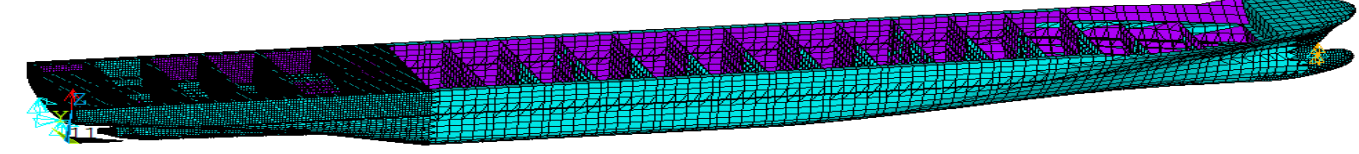

Fig. 1 finite element model of the ship 
According to the calculation requirements and the calculation is convenient, the model of the research institute is only from propeller to the main engine exit, does not take into account the influence of the crankshaft part, at the same time, it does not take into account the flexibility of the bearing seat. In order to calculate the vibration frequency of the shaft, the whole system model of $X$, $\mathrm{Z}$ direction and ROTX, ROTY degrees of freedom are bound up. In X and Y direction get a spring to simulate the bearing. One end of the spring unit is connected to the key point of the axis and the other end is respectively connected to a fixed point in the horizontal and vertical directions, as shown in Figure 2.

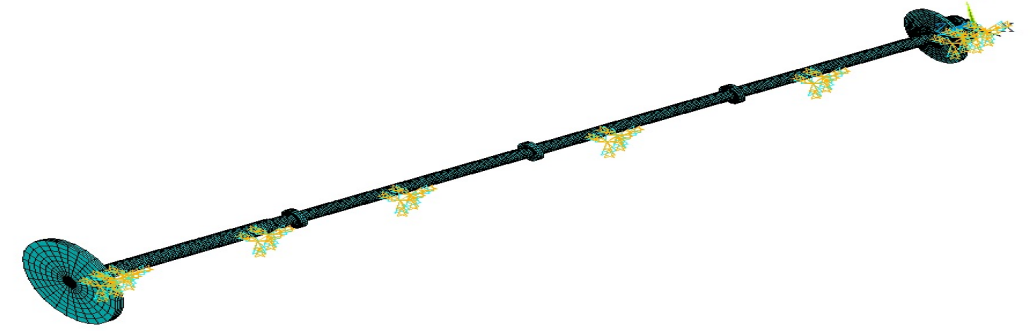

Fig. 2 finite element model of shaft system

\section{Calculation method}

Calculation of wave load: The calculation of regular wave has the following three prerequisites:

(1) the fluid is considered as an ideal condition, that is, the neglect of viscosity and compressibility;

(2) the flow of fluid particles is treated as a potential flow without rotation;

(3) set in the micro wave amplitude under the condition that the relative height of the wavelength is very small.

The motion of regular waves and the model of calculation parameters are shown in Figure 3.

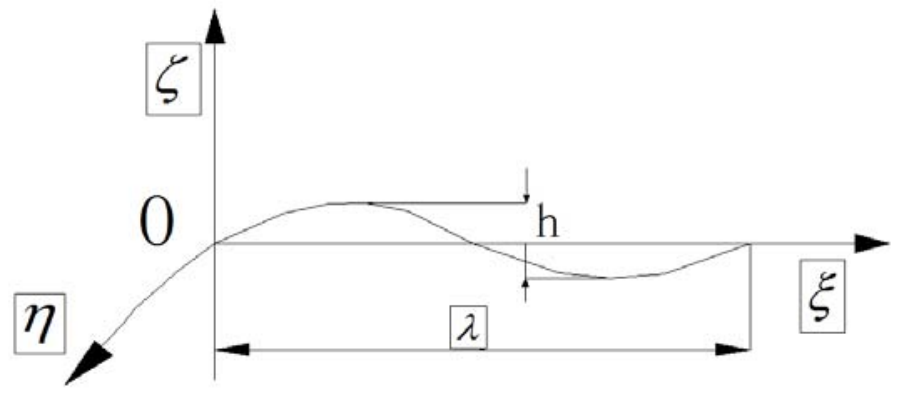

Fig. 3 the rules of wave movement

The pressure expression in the regular wave flow field is as follows:

$$
\Delta P=-\rho \frac{\partial \varphi}{\partial t}-\frac{1}{2} \rho\left(u^{2}+v^{2}+\omega^{2}\right)-\rho g \xi
$$

In the formula , $\rho \frac{\partial \varphi}{\partial t}$ represents the buoyancy of the hull.

$\frac{1}{2} \rho\left(u^{2}+v^{2}+\omega^{2}\right)$ and $\rho g \zeta$ represents the pressure generated by the wave disturbance. The ship on the voyage, in addition to forward speed, the hull will do motions with six degrees of freedom. Select a coordinates with the motion of the ship, set $X$ : forward axis bow direction, positive $Y$ axis : the left of the ship, $\mathrm{Z}$ axis upward. Set origin point in the stern and bottom line intersect the vertical surface, profile, longitudinal profile of the intersection. The angle between the direction of the regular wave and the $\mathrm{X}$ axis is $\beta$. When the ship at sea, $\beta=180^{\circ}$. At any moment, the coordinate system is in the position of the instantaneous equilibrium of the ship's shaking, and the expression of the wave pressure of the deep water rules is as follows

$$
\Delta P=\rho g a e^{\kappa z} \cos \left(\kappa x \cos \chi-k y \sin \chi-\omega_{e} t\right)
$$


The integral of the wave hydrodynamic pressure on the wet surface of the hull, which is expressed as the wave disturbing force and moment acting on the ship's hull:

$$
\begin{aligned}
& F_{W}=-\iint_{s} \Delta P n d S \\
& M_{W}=-\iint_{s} \Delta P(r \times n) d S
\end{aligned}
$$

In the formula , $\mathrm{S}$ - the wet surface area of the hull, $\mathrm{N}$ - the outer normal vector of the $\mathrm{S}$ unit, $r$ the direction to the hull exterior; the position vector of the moving pressure acting point with respect to the ship's coordinate system

Determination of wave parameters: Calculation of hull deformation, generally choose wave bending moment is the largest state to study, in order to ensure the safety of ship navigation, according to statistics ${ }^{[5-7]}$, under the equal to the wavelength and the captain, wave bending moment reached the maximum. Therefore, it is the research object of this thesis, take the wave length is $\lambda=320 \mathrm{~m}$, are obtained according to the formula $\omega=2 \pi / 0.8 \sqrt{\lambda}$ conversion wave frequency 0.4 .

In addition according to the sea wave statistics data display, global oceans appeared frequently in the sea for three to five waves, above the 6wave frequency is low. According to the regulation of China Marine Bureau wave level, five waves $2.5 \leq H_{1 / 3} \leq 4.0$, 6 wave $4.0 \leq H_{1 / 3} \leq 6.0, H_{1 / 3}$ for significant wave height. So take more common wave height $\mathrm{H}=4 \mathrm{~m}$ and limit of the sea wave height under the $\mathrm{H}=6 \mathrm{~m}$ as the wave height, wave flow direction bow attack wave, incident angle is 180 degrees. Therefore, it can be calculated wave height along the $\mathrm{X}$ direction of the captain with the spatial variation equation are obtained:

$\eta=4 \cdot \cos (x \cdot 160 / \pi+\varphi)$

From 0 degree to 360 degrees every 30 degrees selected phase were calculated, the ship at different phase angles of wave force is calculated and a total of 12 different phase, resulting in the different phase of hull deformation. As a result, the wave calculation parameters such as table 1 shows

Tab.1 wave parameter list

\begin{tabular}{lcclcl}
\hline $\begin{array}{l}\text { Wave } \\
\text { parameters }\end{array}$ & $\begin{array}{c}\text { wave } \\
\text { height } \\
(\mathrm{m})\end{array}$ & $\begin{array}{c}\text { wavele } \\
\text { ngth } \\
(\mathrm{m})\end{array}$ & $\begin{array}{c}\text { frequency } \\
(\mathrm{Hz})\end{array}$ & phase $\left({ }^{\circ}\right)$ & Wave direction \\
\hline condition1 & 4 & 320 & 0.4 & $0 \sim 360$ & Head sea \\
condition2 & 6 & 320 & 0.4 & $0 \sim 360$ & Head sea \\
\hline
\end{tabular}

Calculation of the stiffness of the lubricating oil film of shaft system: Because of the lubrication system, so in the state of the shafting system, between the bearing and the rotor will have oil film, resulting in the axis position is not fixed, the at the same time, bearing reaction force has also undergone a change, its numerical and static state of the bearing reaction force is not the same. The Reynolds equation for radial sliding bearing oil film motion:

$$
\frac{\partial}{\partial s}\left(\frac{h^{3}}{12 \mu} \frac{\partial p}{\partial s}\right)+\frac{\partial}{\partial z}\left(\frac{h^{3}}{12 \mu} \frac{\partial p}{\partial z}\right)=\frac{U}{2} \frac{\partial h}{\partial s}+\frac{\partial h}{\partial t}
$$

$\mathrm{U}$ in the above equation, $\mathrm{h}$ and $\mu$ are surface line speed of the rotor pressure, oil film thickness and viscosity. The dimensionless equation above, can be drawn:

$\frac{\partial}{\partial \theta}\left(H^{3} \frac{\partial}{\partial \theta}\right)+\left(\frac{R}{L}\right)^{2} \frac{\partial}{\partial Z}\left(H^{2} \frac{\partial P}{\partial Z}\right)=-\left(\left[\dot{X}+\frac{Y}{2}\right]+Z\left[\alpha+\frac{\beta}{2}\right]\right) \cos \cos \theta\left(\left[\dot{Y}-\frac{X}{2}\right]+Z\left[\frac{\alpha}{2}\right]\right) \sin \sin \theta$

According to the boundary conditions provided above, the equation of the oil film stiffness and damping can be obtained: 
$\mathrm{K}=\left[\begin{array}{ll}\kappa_{x x} & \kappa_{x y} \\ \kappa_{y x} & \kappa_{y y}\end{array}\right]=\left[\begin{array}{ll}\frac{f_{x}(x+\Delta x, y)-f_{x}(x, y)}{\Delta x} & \frac{f_{x}(x, y+\Delta y)-f_{x}(x, y)}{\Delta y} \\ \frac{f_{y}(x+\Delta x, y)-f_{y}(x, y)}{\Delta x} & \frac{f_{y}(x, y+\Delta y)-f_{y}(x, y)}{\Delta y}\end{array}\right]$
$C=\left[\begin{array}{ll}c_{x x} & c_{x y} \\ c_{y x} & c_{y y}\end{array}\right]=\left[\begin{array}{ll}\frac{f_{x}(x, y, \Delta x, 0)-f_{x}(x, y, 0,0)}{\Delta x} & \frac{f_{x}(x, y, 0, \Delta y)-f_{x}(x, y, 0,0)}{\Delta y} \\ \frac{f_{y}(x, y, \Delta x, 0)-f_{y}(x, y, 0,0)}{\Delta x} & \frac{f_{y}(x, y, 0, \Delta y)-f_{y}(x, y, 0,0)}{\Delta y}\end{array}\right]$

\section{Calculation and analysis}

Calculation of the deformation of the bearing: Air pressure on container ships, the hydrostatic pressure loads and wave dynamic pressure load, and then bound to the boat a little as inertia free computation load under the condition of hull deformation, tail extraction a total of 11 bearing (the ship shafting bearing from the exit of propeller shaft sequentially numbering 1\#, 2\#, 3\#, 4\#, 5\#, 6\#, 7\#, $8 \#, 9 \#, 10 \#, 11 \#$ position vertical to the displacement, the stern shaft export $1 \#$ bearing and engine room bulkhead at $8 \#$ bearing displacement for reference, the obtained ship propulsion shafting with waves over a total of 12 kinds of phase of deformation, shaft deformation data for shown in the table below

Tab. $24 \mathrm{~m}$ wave bearing deformation $(\mathrm{mm})$

\begin{tabular}{|c|c|c|c|c|c|c|c|c|c|c|c|c|}
\hline phase & $0^{\circ}$ & $30^{\circ}$ & $60^{\circ}$ & $90^{\circ}$ & $120^{\circ}$ & $150^{\circ}$ & $180^{\circ}$ & $210^{\circ}$ & $240^{\circ}$ & $270^{\circ}$ & $300^{\circ}$ & $330^{\circ}$ \\
\hline $\begin{array}{l}1 \# \\
\text { Bearing }\end{array}$ & 0.00 & 0.00 & 0.00 & 0.00 & 0.00 & 0.00 & 0.00 & 0.00 & 0.00 & 0.00 & 0.00 & 0.00 \\
\hline $\begin{array}{l}\text { 2\# } \\
\text { Bearing }\end{array}$ & -0.23 & -0.27 & $\begin{array}{l}-0.1 \\
3\end{array}$ & 0.01 & 0.11 & 0.26 & 0.24 & 0.21 & 0.13 & -0.15 & -0.27 & -0.31 \\
\hline $\begin{array}{l}3 \# \\
\text { Bearing }\end{array}$ & -2.42 & -2.01 & $\begin{array}{l}-1.3 \\
2\end{array}$ & $\begin{array}{l}-0.4 \\
1\end{array}$ & 0.32 & 0.80 & 0.93 & 0.57 & -0.27 & -1.12 & -1.81 & -2.34 \\
\hline $\begin{array}{l}4 \# \\
\text { Bearing }\end{array}$ & 0.19 & 1.39 & 2.67 & 3.46 & 3.75 & 3.48 & 2.75 & 1.92 & 1.11 & 0.34 & -0.42 & -0.58 \\
\hline $\begin{array}{l}5 \# \\
\text { Bearing }\end{array}$ & 5.93 & 7.90 & 9.39 & 9.28 & 7.98 & 5.93 & 4.11 & 3.04 & 2.70 & 3.06 & 3.26 & 4.12 \\
\hline $\begin{array}{l}6 \# \\
\text { Bearing }\end{array}$ & 8.45 & 9.94 & $\begin{array}{l}10.5 \\
0\end{array}$ & 9.73 & 7.76 & 5.54 & 3.77 & 2.96 & 3.36 & 4.39 & 5.29 & 6.69 \\
\hline $\begin{array}{l}7 \# \\
\text { Bearing }\end{array}$ & 1.57 & 1.75 & 1.79 & 1.45 & 1.01 & 0.61 & 0.39 & 0.22 & 0.41 & 0.70 & 0.92 & 1.21 \\
\hline $\begin{array}{l}8 \# \\
\text { Bearing }\end{array}$ & 0.00 & 0.00 & 0.00 & 0.00 & 0.00 & 0.00 & 0.00 & 0.00 & 0.00 & 0.00 & 0.00 & 0.00 \\
\hline $\begin{array}{l}9 \# \\
\text { Bearing }\end{array}$ & -3.29 & -3.59 & $\begin{array}{l}-3.5 \\
5\end{array}$ & $\begin{array}{l}-3.1 \\
6\end{array}$ & $\begin{array}{l}-2.3 \\
4\end{array}$ & -1.56 & -0.90 & -0.84 & -1.15 & -1.61 & -2.16 & -2.62 \\
\hline $\begin{array}{l}10 \# \\
\text { Bearing }\end{array}$ & -6.62 & -7.32 & $\begin{array}{l}-7.4 \\
6\end{array}$ & $\begin{array}{l}-6.4 \\
1\end{array}$ & $\begin{array}{l}-4.7 \\
4\end{array}$ & -3.11 & -2.04 & -1.78 & -2.32 & -3.34 & -4.32 & -5.47 \\
\hline $\begin{array}{l}11 \# \\
\text { Bearing }\end{array}$ & -10.25 & -11.40 & $\begin{array}{l}-11 . \\
41\end{array}$ & $\begin{array}{l}-9.9 \\
3\end{array}$ & $\begin{array}{l}-7.4 \\
5\end{array}$ & -4.92 & -3.12 & -2.73 & -3.68 & -5.28 & -6.71 & -8.51 \\
\hline
\end{tabular}


Tab.3 $6 \mathrm{~m}$ wave bearing deformation (mm)

\begin{tabular}{|c|c|c|c|c|c|c|c|c|c|c|c|c|}
\hline nase & $0^{\circ}$ & $30^{\circ}$ & $60^{\circ}$ & $90^{\circ}$ & $\begin{array}{l}120 \\
\circ\end{array}$ & $\begin{array}{l}150 \\
0\end{array}$ & $\begin{array}{l}180 \\
\circ\end{array}$ & $\begin{array}{l}210 \\
0\end{array}$ & $\begin{array}{l}240 \\
\circ\end{array}$ & $\begin{array}{l}270 \\
0\end{array}$ & $\begin{array}{l}300 \\
\circ\end{array}$ & $\begin{array}{l}330 \\
0\end{array}$ \\
\hline $\begin{array}{l}1 \# \\
\text { Bearing }\end{array}$ & 0.00 & 0.00 & 0.00 & 0 & 0 & 0 & 0 & 0 & & 0 & $\begin{array}{l}0.0 \\
0\end{array}$ & $\begin{array}{l}0.0 \\
0\end{array}$ \\
\hline $\begin{array}{l}2 \# \\
\text { Bearing }\end{array}$ & 0.92 & 0.95 & 0.92 & $\begin{array}{l}0.8 \\
9\end{array}$ & $\begin{array}{l}0.8 \\
8\end{array}$ & $\begin{array}{l}0.8 \\
6\end{array}$ & $\begin{array}{l}0.8 \\
2\end{array}$ & $\begin{array}{l}0.8 \\
1\end{array}$ & $\begin{array}{l}0.8 \\
5\end{array}$ & 0.9 & $\begin{array}{l}0.9 \\
4\end{array}$ & $\begin{array}{l}0.9 \\
5\end{array}$ \\
\hline $\begin{array}{l}\text { 3\# } \\
\text { Bearing }\end{array}$ & 5.02 & 473 & 64 & $\begin{array}{l}4.7 \\
6\end{array}$ & $\begin{array}{l}5.0 \\
3\end{array}$ & $\begin{array}{l}5.3 \\
2\end{array}$ & $\begin{array}{l}5.6 \\
2\end{array}$ & $\begin{array}{l}5.9 \\
3\end{array}$ & $\begin{array}{l}5.9 \\
5\end{array}$ & $\begin{array}{l}5.9 \\
2\end{array}$ & $\begin{array}{l}5.6 \\
1\end{array}$ & $\begin{array}{l}5.3 \\
9\end{array}$ \\
\hline $\begin{array}{l}4 \# \\
\text { Bearing }\end{array}$ & 7.20 & 7.12 & 7.11 & $\begin{array}{l}7.1 \\
1\end{array}$ & $\begin{array}{l}7.2 \\
3\end{array}$ & $\begin{array}{l}7.3 \\
0\end{array}$ & $\begin{array}{l}7.4 \\
9\end{array}$ & $\begin{array}{l}7.4 \\
4\end{array}$ & $\begin{array}{l}7.5 \\
3\end{array}$ & $\begin{array}{l}7.4 \\
2\end{array}$ & $\begin{array}{l}7.4 \\
7\end{array}$ & $\begin{array}{l}7.3 \\
9\end{array}$ \\
\hline & $\begin{array}{l}10.2 \\
4\end{array}$ & & & & $\begin{array}{l}9.4 \\
6\end{array}$ & 8.8 & 8.2 & $\begin{array}{l}7.9 \\
4\end{array}$ & 8.0 & 8.4 & $\begin{array}{l}9.0 \\
2\end{array}$ & $\begin{array}{l}9.7 \\
1\end{array}$ \\
\hline $\begin{array}{l}6 \# \\
\text { Bearing }\end{array}$ & 9.22 & 46 & 9.37 & $\begin{array}{l}8.7 \\
8\end{array}$ & $\begin{array}{l}7.8 \\
8\end{array}$ & $\begin{array}{l}6.9 \\
2\end{array}$ & $\begin{array}{l}6.1 \\
2\end{array}$ & $\begin{array}{l}5.8 \\
4\end{array}$ & $\begin{array}{l}6.0 \\
7\end{array}$ & $\begin{array}{l}6.6 \\
8\end{array}$ & $\begin{array}{l}7.5 \\
0\end{array}$ & $\begin{array}{l}8.4 \\
5\end{array}$ \\
\hline $\begin{array}{l}7 \# \\
\text { Bearing }\end{array}$ & 1.84 & 181 & 1.85 & $\begin{array}{l}1.6 \\
3\end{array}$ & $\begin{array}{l}1.3 \\
1\end{array}$ & $\begin{array}{l}1.1 \\
9\end{array}$ & $\begin{array}{l}0.9 \\
1\end{array}$ & $\begin{array}{l}0.9 \\
4\end{array}$ & $\begin{array}{l}0.9 \\
6\end{array}$ & $\begin{array}{l}1.1 \\
8\end{array}$ & $\begin{array}{l}1.3 \\
8\end{array}$ & $\begin{array}{l}1.6 \\
2\end{array}$ \\
\hline $\begin{array}{l}8 \# \\
\text { Bearing }\end{array}$ & 0.00 & 0.00 & 0.00 & $\begin{array}{l}0.0 \\
0\end{array}$ & $\begin{array}{l}0.0 \\
0\end{array}$ & $\begin{array}{l}0.0 \\
0\end{array}$ & $\begin{array}{l}0.0 \\
0\end{array}$ & $\begin{array}{l}0.0 \\
0\end{array}$ & $\begin{array}{l}0.0 \\
0\end{array}$ & $\begin{array}{l}0.0 \\
0\end{array}$ & $\begin{array}{l}0.0 \\
0\end{array}$ & $\begin{array}{l}0.0 \\
0\end{array}$ \\
\hline $\begin{array}{l}9 \# \\
\text { Bearing }\end{array}$ & $\begin{array}{l}-3.1 \\
2\end{array}$ & $\begin{array}{l}-3.3 \\
3\end{array}$ & $\begin{array}{l}-3.2 \\
4\end{array}$ & $\begin{array}{l}-2.8 \\
7\end{array}$ & $\begin{array}{l}-2 . \\
54\end{array}$ & -2. & -1. & $\begin{array}{l}-1 . \\
69\end{array}$ & -1. & $\begin{array}{l}-1 . \\
95\end{array}$ & $\begin{array}{l}-2 . \\
46\end{array}$ & $\begin{array}{l}-2 . \\
81\end{array}$ \\
\hline $10 \#$ & -6 & & -6 . & -5 & -5 & -4 & -3 & -3 & -3 & -4 & -5 & -5 \\
\hline & 4 & 5 & 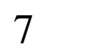 & 3 & 02 & 10 & 56 & 22 & 57 & 12 & 09 & 90 \\
\hline $\begin{array}{l}11 \# \\
\text { Bearing }\end{array}$ & $\begin{array}{l}-10 \\
12\end{array}$ & $\begin{array}{l}-10 \\
43\end{array}$ & $\begin{array}{l}-10 . \\
16\end{array}$ & $\begin{array}{l}-9.2 \\
2\end{array}$ & $\begin{array}{l}-7 . \\
81\end{array}$ & $\begin{array}{l}-6 . \\
59\end{array}$ & $\begin{array}{l}-5 . \\
42\end{array}$ & $\begin{array}{l}-5 . \\
03\end{array}$ & $\begin{array}{l}-5 . \\
47\end{array}$ & $\begin{array}{l}-6 . \\
41\end{array}$ & $\begin{array}{l}-7 . \\
74\end{array}$ & $\begin{array}{l}-9 . \\
19\end{array}$ \\
\hline
\end{tabular}

The influence of the stiffness variation on the natural frequency of the shafting: In order to simulate each bearing in different stiffness of vibration, each spring element for defining real constant alone, so by APDL program conveniently and rapidly changing stiffness, change of shafting vibration oil film stiffness changes.

In order to better analysis of shafting vibration by each individual bearing stiffness change, for further analysis of all the bearing stiffness influence on the shafting vibration ready, only change the stiffness of a bearing and the rest of the stiffness will remain unchanged, and shafting calculation of free vibration natural frequency were calculated, and the tail bearing (7\#), intermediate bearing (4\#) and deformation host export bearings (2\#) on shafting vibration influence, the calculation results as shown below.

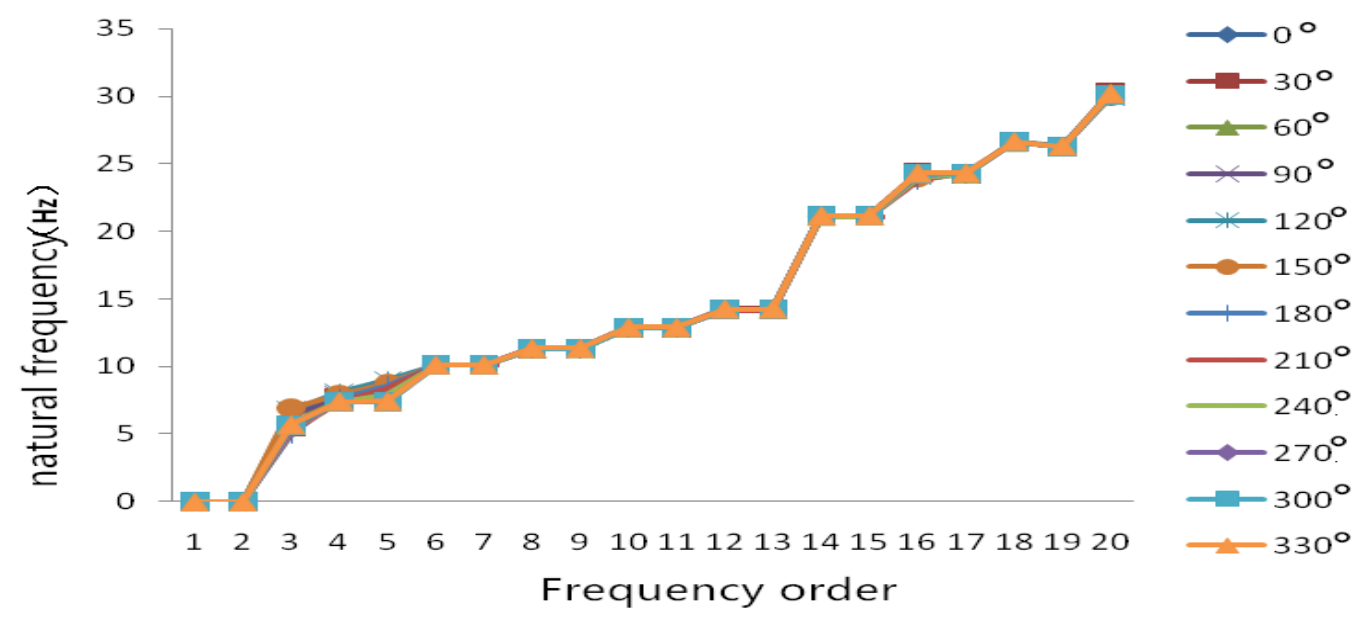

Fig. 4 the influence of the stiffness of the tail bearing (7\#) on the natural frequency 

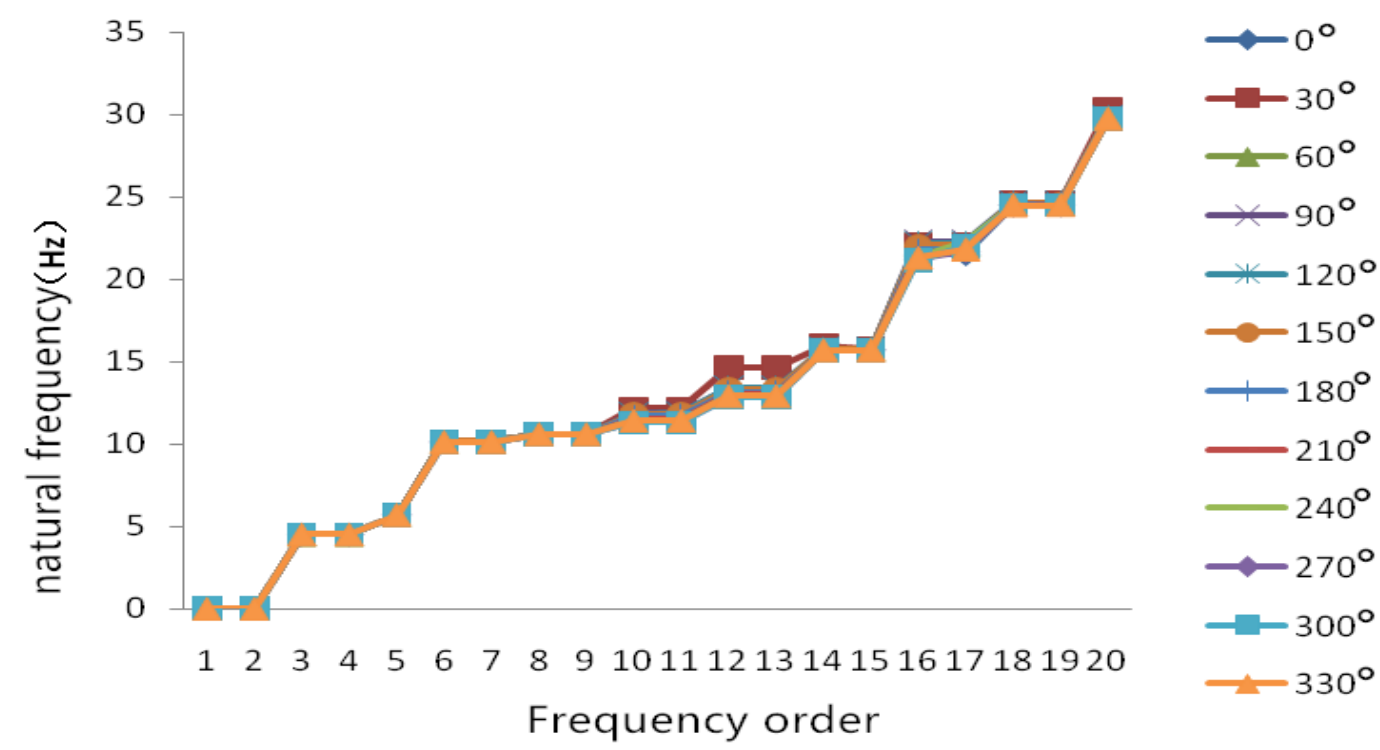

Fig. 5 the influence of the stiffness of the mid bearing (4\#) on the natural frequency

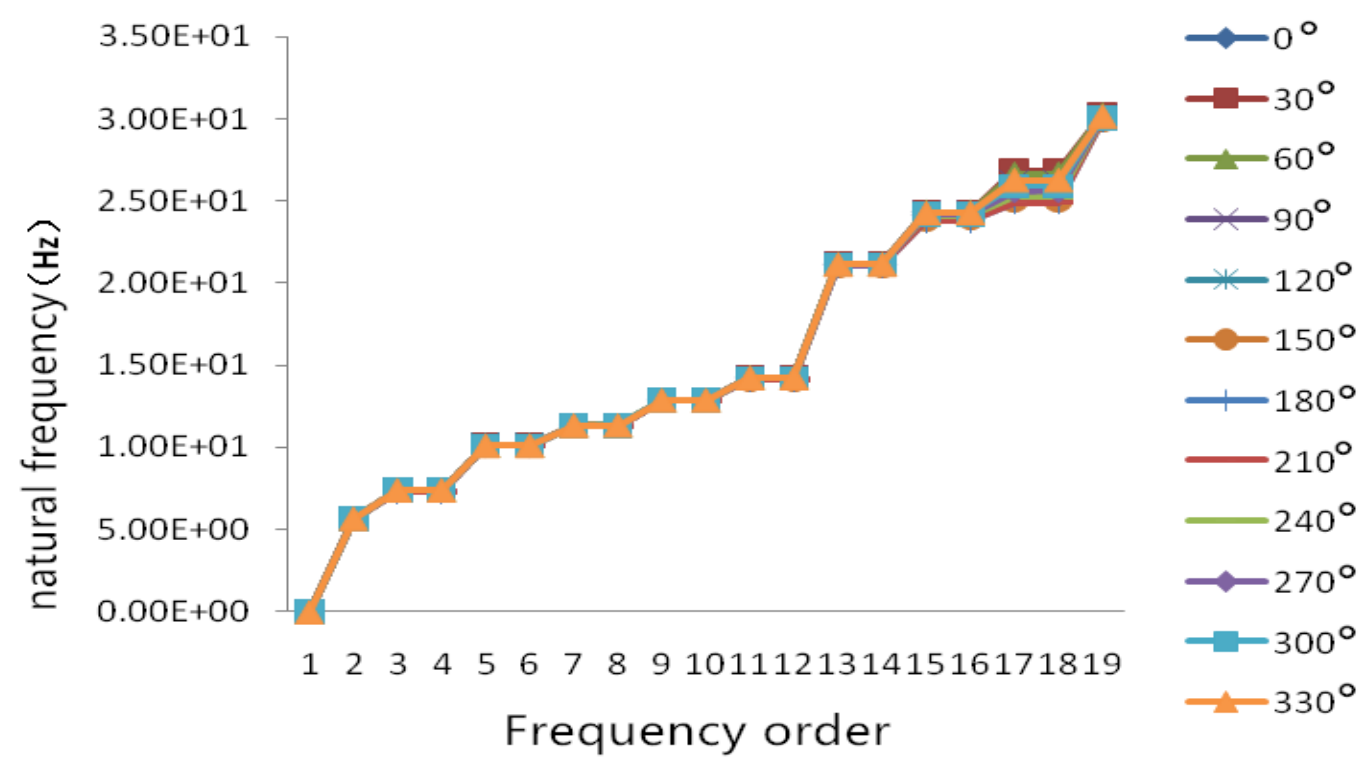

Fig. 6 the influence of the stiffness of the Main engine bearing (2\#) on the natural frequency

From Fig. 4,5,6 can be seen of the stern tube bearing rigidity of shafting natural frequency of low order frequency effect is relatively large, the high order frequency almost had no effect on; and intermediate bearing stiffness changes bring frequency change is mainly reflected in the 10-14 order frequency, host export bearings mainly affects 15 order to the natural frequency.

The influence of all supporting stiffness on the natural frequency of shaft system:According to the oil film bearing the thrust reverser calculation of bearing oil film stiffness, different wave phase of the oil film stiffness were given each bearing is connected to the spring element, and modal analysis, obtained at this time of the transverse vibration of shafting natural frequency distribution. From table 2 and 3 we can see that the wave under the action of oil film bearing stiffness change of shafting transverse vibration frequency is influential, in order to prevent in the running process of the ship shafting happened vibration. Therefore, it is necessary to from time to time, pay attention to the bearing performance changes, including stiffness value and other parameters of the changes. 


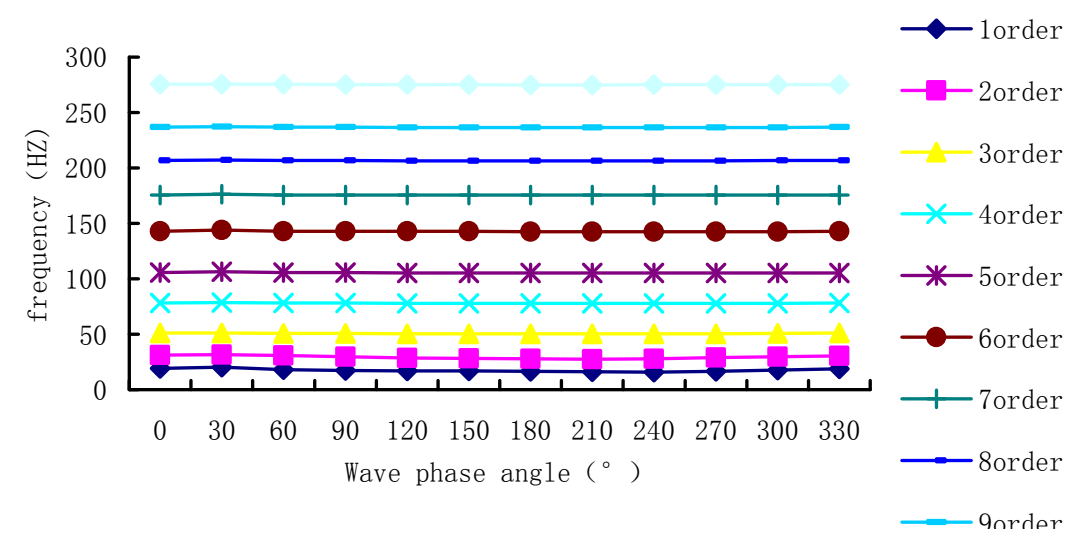

Fig. 5 the natural frequency of the transverse vibration of different support stiffness under high 4m wave

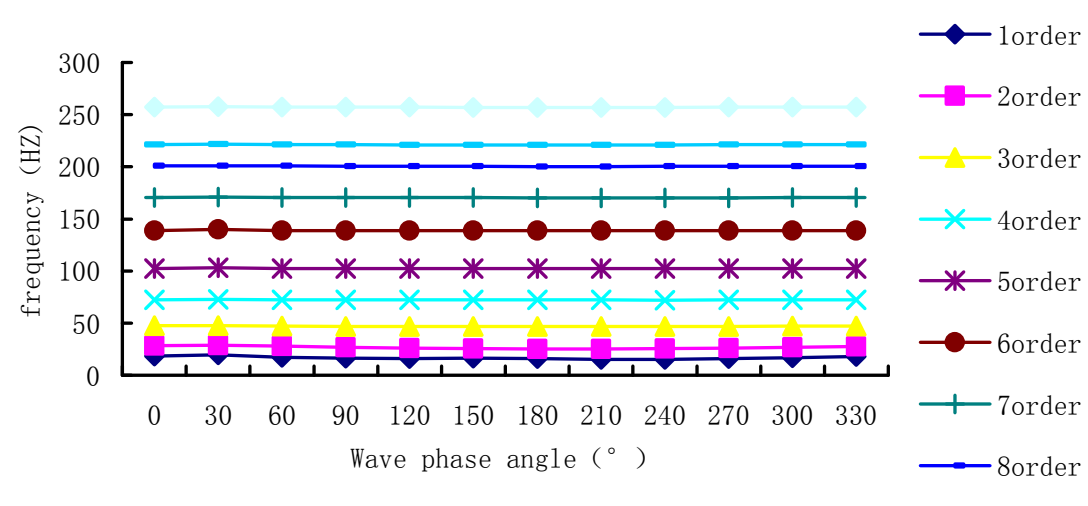

Fig. 6 the natural frequency of the transverse vibration of different support stiffness under

From Figure 5 and 6 we can see that with the changes in the phase of wave, the bearing oil film stiffness variation of shaft vibration frequency has certain influence. In different height, shafting natural frequency is also inconsistent, with the increase of the wave height and bearing oil film stiffness increased, shafting vibration frequency reduces the, total frequency are between $10 \sim 300$, so in shafting design should consider avoiding the frequency range

\section{Conclusion}

According to the bearing displacement and bearing stiffness on the natural vibration characteristics of the shaft can be compared to the following conclusions:

(1) Separate bearing stiffness changes from the point of view, shafting natural frequency of the lower relative impact is greater by the stern bearing rigidity, the higher order frequency almost had no effect on it; the change of the stiffness of the intermediate bearing is mainly reflected in the frequency of the $10 \sim 14$, the main effect of the main export bearing is in the 15 stage natural frequency..

(2) With the changes in the phase of wave, the bearing oil film stiffness variation has certain influence on the shaft vibration frequency. In different height, shafting natural frequency is also inconsistent, with the increase of wave height, bearing oil film stiffness increased, shafting vibration frequency reduced, between $10 \sim 300$ frequency, so people should consider avoiding the frequency range in shafting design.

(3) The bearing oil film stiffness has certain effect on the natural frequency of transverse vibration of shaft system. in order to prevent the excessive vibration of the shafting during the operation of the ship, it is necessary to pay attention to the performance changes of these bearings in real time, including the change of stiffness and other parameters. 


\section{Reference}

[1] Dong Hengjian. Study on the deformation of the hull for shafting alignment [J]. ship engineering,2009 (2) : 8-11

[2] Shi Lei. Calculation of hull deformation for shafting alignment [J]. ship engineering, 2010 (3): 13-16

[3] Zhu Yunzhao. Influence of hull deformation on attitude parameters and measurement [J]. micro computer information, 2008 (8): 285-287.

[4] Zhu Yunzhao. Overview of ship hull deformation measurement technology [J]. ship engineering, 2007 (6): 58-61.

[5] Wu Tan. The deformation and stress analysis of large container ship propulsion shafting bearing point [D]. Wuhan University of Technology 2013

[6] Tang forces. Large container ship 3D wave load computation[D].Wuhan University of Technology 2008

[7] He Liz. Analysis of dynamic response of super large ship in waves [D]. Wuhan University of Technology 2013 